\title{
Malignant Sertoli Cell Tumor
}

National Cancer Institute

\section{Source}

National Cancer Institute. Malignant Sertoli Cell Tumor. NCI Thesaurus. Code C67006.

A Sertoli cell tumor of the testis or the ovary which metastasizes to another anatomic site. 